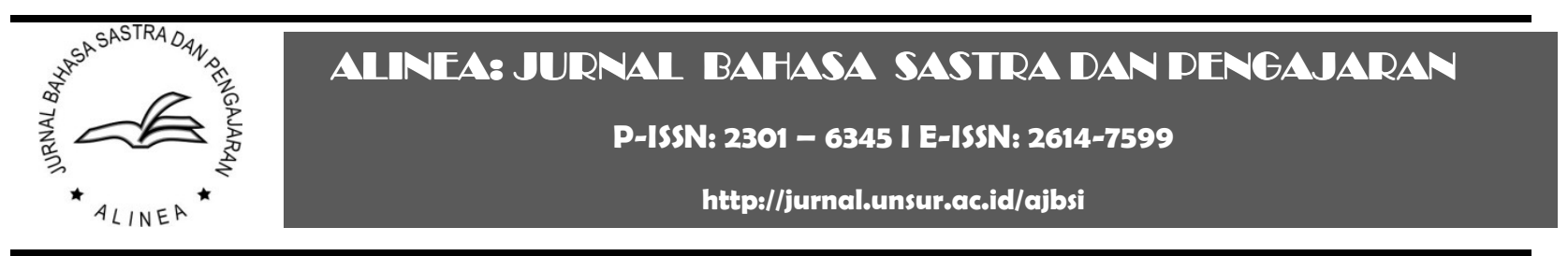

\title{
PENINGKATAN KEMAMPUAN SISWA DALAM MENULIS KREATIF PUISI DENGAN MEDIA GAMBAR
}

\author{
Popon Nuraeni \\ SMPN 1 Sukalarang
}

Riwayat artikel:

Dikirim: 29 September 2019

Direvisi: 02 Oktober 2019

Diterima: 7 Oktober 2019

Diterbitkan: 30 Oktober 2019

Katakunci:

media gambar

menulis

puisi

Alamat surat

poponnuraeni@gmail.com

\begin{abstract}
Abstrak:
Artikel ini memaparkan peningkatan kemampuan siswa dalam menulis puisi dengan menggunakan media gambar. Penelitian dilaksanakan dua siklus setiap siklus dilaksanakan dalam empat tahapan yaitu tahap perencanaan, tahap pelaksanaan tindakan, tahap observasi dan evaluasi, tahap analisis refleksi. Teknik pengumpulan data menggunakan dokumentasi, tes, dan observasi. Hasil penelitian menunjukkan bahwa pada siklus pertama belum menunjukan peningkatan kemampuan. Hal ini dibuktikan dengan rata-rata nilai hanya mencapai 78.08. Pada siklus ke dua pembelajaran meningkat, dengan nilai rata-rata siswa 83,19. Siswa yang aktif pada pertemuan ke dua berjumlah 32 siswa dari 36 siswa, ( 88, 88\%). Hasil penelitian terbuki berdampak positif, (1) pelaksanaan pembelajaran dengan media gambar dapat berjalan dengan baik, (2) dapat meningkatkan kreativitas siswa, dan (3) meningkatkan hasil belajar.
\end{abstract}

\begin{abstract}
:
This article describes the improvement of students' abilities in writing poetry using picture media. The study was carried out in two cycles with four stages for each cycle, namely planning, implementation of the action, observation and evaluation, reflection analysis stage. Data collection techniques used documentation, tests, and observations. The results show that the first cycle did not show an improvement of students' ability. It was evidenced by the average value of only 78.08. In the second cycle of learning, it increased with an average value of students' score 83.19. Students who were active at the second meeting were 32 students from total 36 students $(88,88 \%)$. The results of the research show positive impacts (1) the implementation of learning with picture media can work well, (2) it can improve students' creativity, and (3) improve learning outcomes.
\end{abstract}

\section{PENDAHULUAN}

Sastra adalah pembayangan atau pelukisan kehidupan dan pikiran imajinatif ke dalam bentuk-bentuk dan struktur-struktur bahasa (Tarigan). Salah satu jenis sastra adalah puisi. Istilah puisi yang sekarang digunakan menurut Fauji berasal dari bahasa latin yakni poesis, yang berarti penciptaa, atau poieo yang berarti seni tertulis, di mana para penulisnya disebut 'poet', yakni orang yang mencipta lewat tulisan, hampir disejajarkan dengan dewa (Fauji).
Dalam Kurikulum Tingkat Satuan Pendidikan (KTSP) SMP kelas VII terdapat pembelajaran menulis sastra dengan Standar Kompetensi dan beberapa Indikator Kompetensi dasar yaitu menulis puisi kreatif peristiwa yang pernah dialami.

Kenyataan di lapangan, pelajaran menulis puisi kurang diminati siswa dengan minimnya pengetahuan siswa terhadap sastra, kurangnya hasil karya sastra siswa menandakan rendahnya minat siswa terhadap sastra. Hal ini dikarenakan siswa kurang dibiasakan untuk menulis karya sastra, sastra memiliki 
jangkauan yang sangat luas. Jangkauan materi ini apabila dibandingkan dengan guru yang kurang memadai, sarana yang minim, serta alokasi waktu yang sempit, maka pengajaran sastra tidak akan berjalan dengan baik sebagaimana mestinya.

Hal-hal yang berhubungan dengan kekurang berhasilan pengajaran sastra di sekolah sudah lama dipersoalkan. Rusyana mengemukakan, sudah sejak kira-kira tahun 1955 masalah pengajaran sastra, khususnya apresiasi sastra dipermasalahkan oleh sastrawan dan pengajar sastra karena dirasakan tidak memenuhi harapan (Rusyana). Untuk menanggulangi permasalahan tersebut perlu diujicobakan sebuah strategi pembelajaran.

Suparman mengemukakan bahwa strategi pembelajaran merupakan perpaduan dari urutan kegiatan, cara mengorganisasikan materi pelajaran peserta didik, peralatan dan bahan, dan waktu yang digunakan dalam proses pembelajaran untuk mencapai tujuan pembelajaran yang telah ditentukan (Suparman).

Penelitian tindakan kelas ini mengujicobakan menulis puisi kreatif melalui media gambar. Kegiatan menulis puisi ini, dilakukan siswa sesuai dengan peristiwa yang pernah dialami siswa sendiri. Dalam hal ini penelitian berusaha mengubah strategi dan pembelajaran yang kurang menarik dan membuat jenuh anak dengan strategi supaya anak menjadi senang dan lebih semangat dalam belajar karena ternyata dari penelitian yang dilakukan Budiansyah juga yang dilakukan oleh Nurhayati, penggunaan media gambar, bisa meningkatkan kemampuan menulis siswa (Budiansah; Nurhayati).

Penelitian itu ada kesamaan penelitian yaitu sebuah strategi dengan menggunakan media gambar dalam pembelajaran menulis, bedanya secara khusus pada penelitian di atas lebih menekankan pada tujuan komunikatif menulis esai. Penelitian lainnya penggiringan imajinasi menulis puisi secara umum, sementara yang penulis teliti adalah media tersebut diujicobakan dalam menulis kreatif puisi pengalaman yang pernah dialami siswa sesuai dengan KD yang tercantum dalm silabus dalam pemilihan gambar pendekatannya ditekankan pada peristiwa-peristiwa yang terjadi. Jadi ada perbedaan dalam tujuan kompetensi dasarnya.

Pada pembelajaran ini penulis menyediakan media gambar yang disukai siswa dalam bentuk gambar dengan tujuan lebih merangsang kemampuan siswa dalam menulis puisi peristiwa yang pernah dialaminya.

Berdasarkan pernyataan di atas, tulisan ini akan mebahas kemampuan siswa kelas VII BSMPN 1 Sukalarang Sukabumi dalam menulis puisi dengan menggunakan media gambar.

Selanjutnya, akan dipaparkan hal-hal yang berkaitan dengan puisi sebagai bahan pembelajaran. Juga akan dipaparkan hal-hal; yang berkaitan dengan media gambar.

\section{Puisi}

Puisi adalah bentuk karya sastra yang menggunakan kata - kata indah dan kaya makna. Keindahan sebuah puisi disebabkan oleh diksi, majas, rima dan iramayang terkandung dalam karya sastra tersebut.

Secara garis besar unsure-unsur terbagi dalam dua macam yaitu struktur fisik dan struktur batin. Menurut Herman J. Waloyo (1995) puisi dibangun dari unsur fisik meliputi diksi, pengimajian kata konkrit, bahasa figurative, rima/ritma, dan tata wajah, diksi (pemilihan kata), pengimajian, kata-kata kongkrit, bahasa figuratif (majas), rima / ritma, dan tata wajah atau tipografi (Waluyo).

Adapun hal-hal yang diungkapkan penyair meliputi tema puisi, b.tema ketuhanan (religius), c. tema kemanusiaan, d. tema patriotisme, e. cinta tanah air, f. tema cinta kasih antara pria dan wanita, tema kerakyatan atau demokrasi, h. tema keadilan sosial, i. tema pendidikan, budi pekerti, tema-tema lain, 
nada dan suasana puisi, perasaan dalam hati, dan amanat puisi.

Dalam perjalanan hidup ini, setiap orang pasti pernah mengalami kejadian-kejadian yang sangat menarik. Kejadian-kejadian itu sebenarnya bisa kita ungkapkan dalam bentuk puisi.berikut adalah hal-hal yang di perlukan untuk menyusun puisi berdasarkan pengalaman pribadi. Menentukan pengalaman paling menarik yang bisa di tulis jadi puisi, menulis pengalaman-pengalaman itu, memilih kata-kata yang memiliki makna kias atau berlatih terus menerus untuk menulis puisi yang baik, dan berani untuk sekali-kali mempublikasikan puisi yang pernah di tulis.

\section{Media Pembelajaran}

Kata media berasal dari bahasa latin medium yang berarti "perantara" atau "pengantar". Pengertian media mengarah pada sesuatu yang mengantarkan atau meneruskan informasi dari pengirim pesan kepada penerima pesan.

Briges mengemukakan bahwa media adalah segala sesuatu alat fisik yang dapat menyajikan pesan serta merangsang siswa untuk belajar (Sadiman), contohnya buku, kaset, dan film. Sedangkan, Sudjana dan Rivai mengatakan bahwa media pengajar merupakan alat bantu mengajar yang ada dalam komponen metodologi pengajaran, sebagai salah satu lingkungan belajar yang diatur oleh guru (Sudjana and Rivai).

\section{Nilai dan Manfaat Media Pembelajaran}

Menurut Sudjana dan Rivai media pengajar memiliki beberapa manfaat diantaranya (a) Pengajar akan lebih menarik perhatian siswa dapat menimbilkan motivasi belajar, (b) Bahan pengajar akan lebih jelas maknanya sehingga dapat lebih dipahami oleh para siswa, (c) Metode pengajar akan lebih bervariasi, tidak semata-mata komunikasi verbal melalui penuturan kata-kata oleh guru sehingga siswa tidak biosan dan guru tidak kehabisan tenaga; dan (d) Siswa lebih banyak melakukan kegiatan belajar tidak hanya mendengarkan uraian guru, tetapi juga aktivitas lain seperti mengamati, melakukan dan mendemonstrasikan (Sudjana and Rivai).

\section{Jenis dan Kriteria Media Pembelajaran}

Lebih lanjut, dijelaskan bahwa ada beberapa jenis media pembelajaran yang biasa digunakan dalam pembelajaran, yaitu (1) Media garafis atau media dua dimensi, (2) Media tiga dimensi, (3) Media proyeksi, dan (4) Lingkungan

\section{METODE}

Penelitian ini dilakukan di kelas VII di SMP Negeri 1 Sukalarang Kabupaten Sukabumi pada semester tahun 2 tahun ajaran 2014 / 2015 dengan jumlah siswa sebanyak 36 siswa yang terdiri dari atas 22 siswa laki - laki dan 18 siswa perempuan. Karakteristik siswa di kelas ini adalah memiliki karakteristik sama seperti kelas-kelas yang lain,artinya tingkat kemampuan belajar cenderung sama dengan kelas yang lainnya.

Faktor yang diamati adalah kemampuan siswa dalam menulis kreatif puisi yang berkenaan dengan peristiwa yang pernah dialami, faktor media yang digunakan, faktor guru.

Dari faktor siswa yang diamati adalah kreatifitas siswa dalam menulis puisi, pemahaman identifikasi puisi yang di tulis, dan daya serap siswa terhadap pembelajaran. Faktor media yang diamati adalah fungsi media yang di gunakan, kelebihan media, dan media sebagai daya tarik siswa. Faktor guru yang diamati adalah keterampilan guru dalam memilih media gambar, keterlibatan guru membantu siswa dalam mendiagnosis kebutuhan belajar, menyusun tujuan belajar, memilih media, merancang pola-pola pengalaman belajar, dan melakukan evaluasi

Metode penelitian yang digunakan adalah metode deskriptif untuk pembuatan silabus pembelajaran, RPP, dan melaksanakan 
pembelajaran menulis kreatif puisi. Sedangkan tindakan kelas digunakan untuk meneliti dan sekaligus memperbaiki pembelajaran di sekolah,khususnya dalam menulis kreatif puisi yang berkenaan dengan peristiwa yang pernah dialami dengan media gambar di kelas VII B SMP Negeri 1 Sukalarang Kabupaten Sukabumi tahun pelajaran 2014/2015.

Teknik penelitian menggunakan adalah studi dokumentasi, tes, dan observasi. Pelaksanaan pembelajaran ini diobservasi oleh dua orang observer seperti yang telah disebutkan di atas. Setelah digabungkan dari dua observer. Tujuan Perbaikan meningkatkan kreatifitas siswa dalam menulis puisi yang berkenaan dengan peristiwa yang pernah dialami melalui media gambar.

Pelaksanaan tindakan dalam penelitian ini akan dilakukan melalui pelaksanaan pembelajaran sesuai perencanaan tindakan. Pelaksanaan tindakan direncanakan terbagi dalam siklus penelitian

Siklus-1

Pertemuan ke 1 siswa mengidentifikasi tentang peristiwa yang pernah dialami, kemudian memilih salah satu peristiwa yang pernah dialami. Siswa menulis puisi dengan pilihan kata yang tepat dan rima yang menarik

Pertemuan 2 siswa melakukan diskusi kelompok untuk mengamati puisi yang telah dibuat sebelumnya dengan mengidentifikasi pilihan kata yang kurang tepat dan mengidentifikasi rima puisi yang kurang baik. Siswa melakukan penyutingan puisi yang ditulis teman sekolompoknya. Siswa mengidentifikasi pilihan kata yang kurang tepat. Siswa mengidentifikasi rima puisi yang kurang tepat. Siswa memilih puisi terbaik dikelompoknya untuk ditampilkan di depan kelasnya

Siklus ke-2

Pertemuan ke 1 sebelum siswa mengidentifikasi tentang peristiwa yang dialami, guru menjelaskan tentang tujuan pembelajaran yang akan dipelajari. Siswa menulis salah satu peristiwa yang pernah terjadi untuk dijadikan puisi dengan menggunakan kata yang tepat dan rima yang menarik dengan melihat media gambar.

Pertemuan 2 siswa duduk berkelompok melakukan penyuntingan hasil penulisan teman sekelompoknya dengan media gambar kemudian dibuatkan puisinya sesuai gambar peristiwa yang terdapat dalam media gambar yang dibagikan guru. Siswa memilih puisi terbaik di kelompoknya untuk diwakilkan dibaca di depan kelasnya. Perwakilan kelompok membaca puisi di depan. Kelompok yang lain menilai. Diskusi kelas memberikan penilaian setiap perwakilan yang maju di depan. Penentuan siswa pembaca terbaik. Siswa dan guru mengadakan refleksi

\section{HASIL DAN PEMBAHASAN}

\section{Hasil Penelitian}

Pada pertemuan pertama, kegiatan awal dimulai dengan mengkondisikan kelas. Dalam mengkondisikan kelas, guru menertibkan siswa, mengabsen, mengecek kembali persiapan mengajar, sarana pembelajaran, sumber dan alat peraga berupa ragam gambar peristiwa.

Apresiasi, pada tahap apresasi, guru menjelaskan tentang kompetensi dasar yang akan dipelajari, menjelaskan tujuan pembelajaran yang akan dipelajari dan menjelaskan tentang materi yang pernah di pelajari siswa tentang menulis pengalaman yang pernah dialami.

Kegiatan inti. siswa memperhatikan media yang dipasang guru, berupa gambargambar dengan pilihan gambar pemandangan, bunga, binatang, peristiwa bencana alam, dan kemudian siswa mengidentifikasikan tentang peristiwa yang dialami dengan contoh media gambar tersebut. Setelah melihat contoh gambar itu, siswa diberi tugas untuk memilih salah satu pertistiwa yang pernah dialami untuk dijadikan puisi. Kemudian siswa 
berlatih menulis larik-larik puisi dengan pilihan kata yang tepat dan rima yang menarik.

Kegiatan akhir, siswa dan guru mengadakan tanya jawab tentang penyusunan puisi itu, dan mengumpulkan hasil pekerjaan individual siswa tentang puisi yang telah ditulisnya dan hasilnya kurang memuaskan . Kemudian guru menginformasikan kegiatan pada pertemuan berikutnya.

Pertemuan kedua, kegiatan dimulai dengan mengkondisikan kelas, guru menertibkan siswa, mengabsen, mengecek kembali persiapan mengajar, sarana pembelajaran, sumber dan alat peraga. Menyampaikan informasi tentang hasil pembelajaran pada pertemuan pertama serta mengadakan tanya jawab tentang hasil puisi yang telah ditullis siswa pada pertemuan pertama. Selanjutnya siswa berkelompok, dan penulis menjelaskan kegiatan berikuktnya.

Selanjutnya, dalam kegiatan inti siswa dibagi dalam kelompok, siswa bertukar hasil puisinya. Setiap siswa menyunting hasil puisi temanya dari pilihan kata dan rimanya dengan cara mengamati dan menilainya, setiap kelompok memilih puisi terbaik di kelompoknya untuk ditampilkan di depan, kemudian perwakilan kelompok atau puisi terbaik dibacakan di depan kelas dan kelompok lain menilai dengan format penilaian yang sudah disediakan penulis

Kegiatan akhir setelah siswa tampil, setiap kelompok memberikan penilaian. Dalam kegiatan ini membacakan puisi di depan kelas. Kemudian diberikan test individu. Dalam kegiatan akhir ini penulis dan siswa memberikan penghargaan kepada siswa yang telah membuat puisi yang terbaik, kemudian siswa dan guru mengadakan refleksi tentang kegiatan hari ini, dan menyimpulkan materi yang telah dipelajari

Observasi pembelajaran dapat dilihat dari dua aspek. Pertama penilaian individual, yaitu tentang menulis puisi dengan piliahan kata yang tepat dan rima yang menarik. Kedua nilai kelompok melalui perwakilan siswa yang tampil di depan kelas

\section{Temuan Penelitian}

Deskripsi temuan pada pertemuan ke satu guru memberikan penjelasan umum tentang materi tetapi belum memberikan KBM yang dilakukan. Kemudian siswa mengamati media gambar dengan baik namun belum menekankan pada pengidentifikasikan pada peristiwa yang belum dialami siswa. Beberapa siswa masih bingung mengikuti pelajaran. Guru belum mendorong siswa untuk bertanya. Ketika tampil siswa masih kelihtan malumalu. Selesai pembelajaran tidak ada tugas rumah. pembelajaran belum sesuai dengan skenario yang ada di RPP. RPP masih perlu diperbaiki. Proses inquiri anak belum maksimal.

Refleksi media gambar yang digunakan belum mampu memotivasi keberanian siswa untuk bertanya, dan proses inquiri anak belum maksimal. Tindak lanjut pada siklus ke duan media gambar yang digunakan diubah dengan tema yang lebih menyentuh pada kehidupan anak kemudian di identifikasi bersama - sama. Kesesuaian dengan peristiwa yang dialami oleh siswa.

Deskripsi temuan pada pertemuan kedua, tujuan perbaikan meningkatkan reatifitas siswa dalam menulis puisi yang berkenaan dengan peristiwa yang pernah dialami melalui media gambar

Deskripsi temuan guru memberikan penjelasan umum tentang materi dan menggambarkan prosedur kegiatan. Adanya interaksi siswa dan media belajar. Siswa dapat mengikuti alur kegiatan. Guru memberikan arahan dengan bertanya untuk beraktivitas. Guru memberikan tugas rumah. Siswa melaksanakan skenario pemebelajaran dengan baik. Ada perbaikan RPP sesuai dengan prosedur. Proses pembelajaran dilaksanakan dengan baik. 
Refleksi, media gambar yang digunakan dengan strategi yang sesuai dan lancar adanya interaksi dengan media. Tidak lanjut pada siklus ke dua media gambar yang digunakan diubah dengan tema yang lebih menyentuh pada kehidupan anak kemudian diidentifikasi bersama-sama.

Temuan penelitian ada kemiripan dengan temuan penelitian lain, baik yang dilakukan oleh Nurhayati maupun yang dilakukan Budiasnsyah. Nurhayati, misalnya, mengungkapkan ada peningkatan keterampilan menilai siswa dengan diikuti perubahan prilaku siswa dari negatif ke posoitif juga ada peningkatan prosentasi hasil nilai siswa dalam menulis esai Sementara, Budiansyah mengungkapkan terdapat perbedaan yang signifikan anara kemampuan siswa sebelum dan sesudah penggunaan melalui media gambar.

\section{Hasil Pembelajaran Siswa}

Dari hasil individual siswa tentang menulis kreatif puisi yang berkenaan dengan perisiiwa yang pernah dialami, diperoleh gambaran bahwa siswa telah mampu menulis puisi, sebab dari skor ideal 80.

Siklus ke satu pertemuan ke satu, dalam proses pembelajaran siklus pertama pengenalan materi dengan contoh media gambar dan alat peraga berupa charta. Kemudian dilanjutkan dengan mengidentifikasikan gambar dalam alat peraga yang disediakan. Dilanjutkan siswa memilih salah satu peristiwa yang pernah dialami untuk dijadikan puisi dengan pilihan kata yang tepat dan rima yang menarik. Hasil test belum memuaskan dengan nilai rata-rata test individu, 78,08

Pertemuan ke dua, pada pertemuan ini siswa membentuk kelompok untuk mengamati hasil puisi yang dibuat teman sekelompoknya, dengan mengidentifikasikan plihan kata yang kurang tepat dan rima puisi yang kurang baik. Kemudian melakukan penyuntingan puisi teman sekelompok dan memilih satu puisi terbaik untuk ditampilkan di depan. Tiap kelompok menilai kelompok yang lain yang tampil di depan kelas.

Interpretasi pengenalan materi perlu diperjelas dalam kelompok, materi awal belum begitu disukai, akibatnya proses pembelajaran belum maksimal. Pada akhir siklus ke dua ini, hasil pembelajaran sudah memenuhi harapan, yakni adanya peningkatan hasil puisi yang dibuat anak, tercermin dengan pilihan kata dan rima yang dipilih lebih baik dari siklus sebelumnya, dan juga adanya peningkatan keberanian siswa dalam menampilkan atau membacakan puisi hasil karyanya. Untuk tingkat pemula (kelas VII) mereka dimintai cukup dalam menulis puisi. Nilai rata-rata kelompok siklus 2 adalah 83,19.

\section{Pembahasan}

Pelaksanaan model pembelajaran dilaksanakan dengan baik sesuai dengan permasalahn yang harus dipecahkan dalam penilitian ini diperoleh nilai melebihi nilai KKM yaitu 68. Pelaksanaan menulis kreatif dengan pengalaman yang dialami telah berhasil meningkatkan kemampuan anak dalam menulis kreatif puisi. Hasil ini tercermin dari hasil pembelajaran siswa baik nilai individu dengan rata-rata nilai 83,19 maupun hasil kelolmpok dengan rata-rata nilai siswa 81. KBM dalam menulis kreatif puisi cukup baik, dengan menggunakan media gambar. Melalui model belajar dengan menggunakan media gambar dapat meningkatkan motivsi dalam pembelajaran menulis kreatif siswa dan memperbaiki proses belajar mengajar dengan prosentase siswa aktif 88, $88 \%$

Hasil Perbandingan dengan artikel lain tentang media yang menyebukan manfaat media dalam proses pembelajaran adalah memperlancar interaksi antara pembelajar dengan pembelajar sehingga kegiatan pembelajaran akan lebih efektif dan efisien. Tetapi secara lebih khusus. Kesimpulan dan rekomendasi dari penelitian tersebut adalah 
Media merupakan salahsatu komponen pembelajaran. Melalui berbaggai metode dan media pembelajaran akan banyak berinteraksi secara aktif. Media harus dapat kita manfaatkan secara maksimal. Dengan pembelajaran menggunakan media akan meningkatkan proses belajar mengajar, dan meningkatkan kemampuan siswa (Falahudin).

\section{PENUTUP}

Tujuan penelitian ini adalah untuk mendapatkan hasil yang terbaik dalam Pelaksanaan Penelitian Tindakan Kelas (PTK), yang terdiri atas data tentang model pembelajaran, data pelaksanaanya, dan hasil dari model pembelajaran tersebut yang dilaksanakan di kelas VII B semester 2 SMPN 1 Sukalarang Kabupaten Sukabumi.

Dari keseluruhan data hasil penelitian yang telah penulis susun dan telah penulis peroleh. Simpulan dari penelitian ini yaitu pelaksanaan proses belajar mengajar menulis kreatif puisi berkenaan dengan peristiwa yang pernah dialami melalui media gambar di kelas VII B SMPN 1 Sukalarang Kabupaten Sukabumi tahun pelajaran 2014 / 2015 cukup baik, hal ini dapat dibuktikan hasil perolehan nilai siswa baik individu maupun kelompok mendapat nilai yang diatas cukup.

Kreatifitas siswa dalam pembelajaran dengan model pembelajaran melalui media gambar memnunjukan peningkatan. Hal ini dapat memperbaiki sistem pengajaran yang ada, yang selama ini terlihat kecenderungan adanya kurang kreatifnya dalam model mengajar guru. Hasil proses belajar mengajar yang dicapai siswa kelas VII B SMPN 1 Sukalarang Kabupaten Sukabumi tahun pelajaran 2014/2015 cukup baik, hal ini dibuktikan nilai dalam penulisan puisi diatas nilai rata-rata.

Penelitian yang penulis lakukan ini, diharapkan dapat bermanfaat yang lebih luas khususnya pada dunia pendidikan. Berkaitan dengan hal ini, maka penullis menyarankan hal-hal sebagai berikut. Model pembelajaran dengan menggunakan contoh media gambar dapat dipakai dalam pembelajaran sehari- hari, sehingga siswa lebih kreatif dan lebih berani menuangkan perasaannya lewat puisi dan dapat berhasil belajarnya. Dalam proses pembelajaran diharapkan dapat mengikuti model pembelajaran yang telah direncanakan sebelumnya, sehingga pembelajaran akan terarah, tidak akan kabur. Dengan melihat hasil model pembelajaran dengan contoh media gambar, tentunya bisa dikembangkan model-model pembelajaran yang lain.

\section{DAFTAR PUSTAKA}

Budiansah, Andri Firman. "Implementation of Imaginative Sugestion Method by Using Audio Visual Media in Learning Poetry Writing." Alinea: Jurnal Bahasa, Sastra, dan Pengajaran, vol. 2, no. 1, 2019, pp. 28-35, doi:10.35194/alinea.v2i1.500.

Falahudin, Iwan. "Media dalam Proses Pembelajaran.” Jurnal Lingkar Widyaiswara, vol. 1, no. 4, 2014, pp. 104-17.

Fauji, Ahmad Dodi. Menghidupkan Ruh Puisi. Situ Seni, 2019.

Nurhayati, Tuti. "Use of Communicative Aprproach and the Use of Image Media in Improving Writing Skills." Alinea: Jurnal Bahasa, Sastra, dan Pengajaran, vol. 7, no. 2, 2018, pp. 120-34.

Rusyana, Yus. Bahasa dan Sastra dalam Gamitan Pendidikan. CV Diponegoro, 1987. 
Sadiman. Media Pendidikan. Pustekom, 1996.

Sudjana, Nana, and Ahmad Rivai. No Title. Sinar Baru Algesindo, 2010.

Suparman, Atwi. Model Pembelajara. LAN, 1997.

Tarigan, Hendry Guntur. Dasar-Dasar Psikosastra. Angkasa, 1995.

Waluyo, Herman J. Teori dan Apresiasi Sastra. Erlangga, 1995. 